\section{CAUSAS ECONÔMICAS NA PRODUÇÃO DO CRIME}

\section{Luís Lopes Palmeiro}

(Conferência proferida no saläo nobre da Associação. Comercial do Estado, na noite de 21.9.1949.)

\section{Introdução}

O homem está empenhado na luta pela liberdade e pela verdade, pela conservação da espécie e pela sua própria existência. A complexidade dêsses fins obriga-o a atitudes imprevistas, ao mesmo tempo que exige da sua personalidade o poder de adaptação normal entre os mais violentos contrastes. O santo e o herói, o homem comum e o gênio, o homem honesto e o criminoso, diversificando os impulsos e os desejos na eleição dos caminhos de seus próprios destinos.

Em meio aos valores que se afirmam e traduzem as infinitas possibilidades da natureza humana para a beleza e para o bem, surge, possibiloroso contraste, a manifestação negativista do crime.

Ao alcance direto da nossa observação está a inquietadora sucessão dos crimes contra o patrimônio em que as continuadas recaídas revelam um padrão delituoso sistemático.

E' natural que êsses fatos despertam a necessidade de indagar da sua causalidade, se é que se deseja opor-lhes, sincera e decididamente, medidas sábias de prevenção. O homem inteligente e responsável não deseja permanecer em atitude puramente contemplativa, mas muito ao contrário, vai em busca das causas dêsse fenômeno, que põe um acento trágico no seu próprio destino.

O espírito humano, como sempre, fiel ao método de sua lógica interior, estabelecendo categorias de crimes, estabeleceu, também, categorias de causas, sistematizando umas e outras no quadro da sua complicada origem. A tendência inevitável de classificar para sub- meter à meditação e ao estudo, conquanto passível de crítica, é a única que se tem oferecido à ciência para a investigação cuidadosa. $\mathrm{E}$ é, ainda, em nosso caso, o único caminho racional para nos aproximarmos da verdade.

Nos vários estudos etiológicos do crime que se tem feito, procura-se distinguir e identificar as fôrças que regem a conduta humana. Para o psicólogo, o delito constitui um episódio coerente com a individualidade do criminoso. A sua execução representa uma conseqüência absolutamente lógica e fatal do conflito das fôrças e fatôres que o determinam. Os mesmos mecanismos psicológicos intervêm na execução dos atos legais e dos atos delituosos, porém não se compreenderá êsse caráter predeterminado das ações humanas, sem o estudo dos fatôres que o explicam. Compreender e explicar o delito eqüivale, pois, a encontrar o valor das incógnitas na equação responsável pela conduta diante da situação delituosa. $\mathrm{E}$ ' fundamental, portanto, para o jurista, face ao ato ilegal, determinar o papel que, no seu desencadear, desempenham a constituição corporal, o temperamento, a inteligência, o caráter, a prévia experiência de situações análogas, a constelação de causas psíquicas, a situação externa desencadeante, o tipo médio da reação coletiva aplicável à situação, e o modo de perceber essa situação por parte do delinqüente $^{1}$.

$\mathrm{O}$ delinqüente é, segundo William $\mathrm{Healy}^{2}$, o centro dinâmico do problema inteiro do delito. Mas, muitas das fôrças que compõem a personalidade são de potenciais eqüivalentes e resultam num estado de equilíbrio estável, desde que as suas reações se processem dentro nos limites do normal. Para que se não quebre o equilíbrio e permaneçam assim estáveis ou irrompam em explosões cinéticas, elas dependem da natureza ou da intensidade de estímulos, que podem, em cada caso, comportar-se de maneira distinta, positiva ou negativa, favorecendo ou impedindo, somar-se ou opor-se, constituindo o que se denomina de complexos determinantes da conduta normal ou das ações delituosas.

Hans Von Hentig ${ }^{3}$ reconhece, em primeiro lugar, a constituição do indivíduo, pela qual entende a sua maneira normal e fixa de reagir ante estímulos externos e, em segundo lugar, a tremenda variedade de fôrças que atuam sôbre esta disposição, fôrças que podem ser físicas como a temperatura e a umidade, bacteriológicas, como os gér-

1 Aguiar Whitaker - O crime e os criminosos à luz da psicologia e da psiquiatria. ${ }_{2}$ William Healy - The Individual Delinquent, Little Brown and Company, Boston, 1917.
3 Hans Von Hentig - Criminologia, causas y condiciones del delito. Trad. por
Diego Abad de Santillán, Editorial Atalaya, Buenos Ayres, 1948. 
mens da sífilis e da malária, e individuais, como a mulher e o superior, ou culturais.

Em última análise, como acentuava o Prof. Salgado Martins ${ }^{4}$, em recente estudo sôbre a interpretação do crime, êste tem a sua motivação mais forte, mais decisiva, na personalidade profunda e específica do criminoso. O meio social e o meio cósmico condicionam o aspecto da manifestação do delito. Influem, sem dúvida, no seu aparecimento, mas muitos dêsses fatôres de origem social se encontram incorporados ao indivíduo pela herança, pela educação, pelas influências familiares, refletindorse, mais tarde, na conduta do adulto, como parte integrante das suas próprias reações psíquicas, podendo, pois, ser considerados como fatôres da sua etiologia interna.

São, em grandes traços, as fôrças chamadas endógenas e exógenas do delito.

Em nossas observações, constatamos que há predominância, no nosso meio, de crimes contra o patrimônio, crimes que sofrem influência primordial das condições econômicas ambientais.

Para determinar as influências, diretas e indiretas, das fôrças econômicas sôbre a delinqüência, devemos estabelecer a correlação entre as flutuações do aumento do delitos com as cargas econômicas e fixar a classe que ocupa o delinqüente na distribuição da riqueza e a ocupação ou profissão a que se dedica. Ainda, em consonância com êsse método de estudo do problema, fazer, também, o de vários fenômenos e condições econômicas por nós constatados e que nos levaram à crença de que a delinqüência, em todo o tempo e lugar, está condicionada, e, em certa extensão, determinada pela existência de fatôres econômicos, além de outros, identificáveis na sua complexa causalidade.

Entre as causas sociais, a miséria desempenha um papel importante na gênese do delito, porém, seria ingenuidade pressupor que é ela a única personagem do drama criminal ${ }^{5}$.

$\mathrm{Na}$ investigação minuciosa dos fatôres antropológicos e demográficos se poderá verificar que a miséria não sòmente significa a pressão que as tentações das necessidades não satisfeitas exercem sôbre o pobre, mas, também, a causa da degenerescência orgânica e psicológica, transfundindo-se na consciência moral do miserável.

4 Prof. José Salgado Martins - A Interpretacáa Psicanalítica do Delito - Tra.

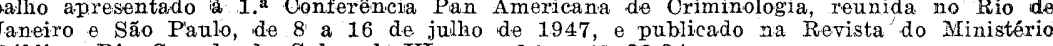

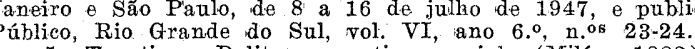

5 Turati-Delito e questione sociale (Milán, 1882). por C. Bernaldo de Quirón, Madrid, 1903 . Mo y la enseñanza de la Criminologia - Trad. Ed. Di. Ftenancisco de Veye Buenos Ayres, Degeneración y Degenerados, Miseria, Vicio y delito.

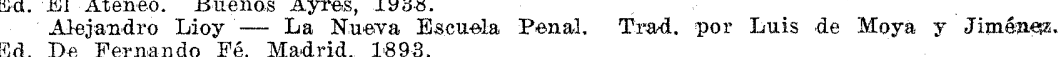

O ambiente de miséria, a fadiga constante, a desnutrição por sistema ocasionam as deformacões individuais, psicológicas e morais, tornando claras e próximas as conexões entre a miséria e o delito.

A difusão do ensino e à índole da educação não se pode emprestar o efeito, vislumbrado por alguns idealistas, que os consideravam como fôrças inibidoras, mas, como bem observa Alfredo $\mathrm{Ni}$ ceforo $^{6}$, o ensino e a educação agrupam-se entre as causas sociais da criminalidade, transformando e, não raro, agravando as suas manifestações.

Existe, conseqüentemente, um delito próprio dos ignorantes e um delito próprio dos homens cultos, do mesmo modo que há uma delinqüêencia característica das múltiplas categorias sociais - o delito do industrial, do pequeno comerciantes, do funcionário público, do proletário, do médico, do advogado, do militar, do rico e do pobre, do homem do campo e do homem torturado da cidade, o delito da paz e da guerra, e o delito da própria civilização?.

Às causas mencionadas, acrescentam-se as variações econômicas da produção, do consumo e do preço das utilidades, relacionadaś ao poder aquisitivo que o valor da moeda empresta às populações.

Comparando as curvas econômicas com o fenômeno do crime, poder-se-ia descobrir as relações existentes entre êste e a cultura da terra, a escassez ou a abundância da produção, o preço das utilidades mais substanciais à vida, o momento industrial e comercial e as oscilações dos salários ${ }^{8}$.

Assim justificamos a singular atenção que estamos dispensando, nesta palestra, às causas econômicas na produção do crime, sem, claro, adotarmos irrestritamente a interpretação chamada socialista. Para essa escola, que assume uma posição ortodoxa entre as teorias que explicam o delito como puro fato social, êste se resume ao fator econômico. Embora reconheçamos o exagêro dessa concepção, ela se explica com aparência impressionante de verdadè, porque, como

a A. Niceforo, obr. eit.

${ }^{7}$ Maurice Parmeles - Criminologia. - Trad. por Julio-Cézar Cerdeiros. Ed. Réns, André Toulemon - Le Progrés des Institutions Pénales (Essai de Sociologie eri-

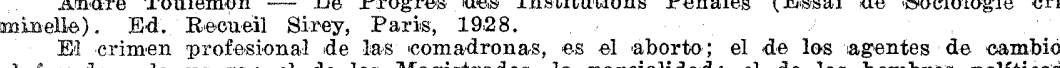
el fraude y la usura; el de los. Magistrados, la parcialidad; el de los hombres politicos,
da corrupcion; el de los publicistas, la calumnia. (E. Laurent, - Le criminel - Pada corrupcion
ris, 1908 .

8 A. Niceforo, obr. cit.

Parmelee, obr. cit.

W. A. Bonger - Criminality and economic conditions - Boston; 1916.

vol. XVI, 1901. La criminalité et les phenomenes économiques, en el Arch. d'Anth. crí, val. Aarofalo - Criminologia - versão portuguêsa de Júlio de Mattos, Ed. Teïxeira * Irmão, Săo Pauło, 1895 
escreve $\mathrm{Van} \mathrm{Kan}^{9}$, entre os fatôrès criminógenos, o fator econômico é o mais móvel, o mais variável, o mais sensível às oscilações anuais e que exercem, portanto, a influência mais visível e mais súbita sôbre o movimento de todos os fenômenos que se ligam ao delito. São as oscilações econômicas, acrescenta o mesmo escritor, caprichosas e bruscas, que constituem, na curva da criminalidade, o elemento perturbador e provocam as diferenças que nela se observam de ano para ano. Nem, tampouco, pretendemos repousar inteiramente sôbre os fundamentos do classicismo, que postula o crime como resultante da vontade livre. Haveria demasia, contudo, em repudiá-lo, por completo, porque, afinal de contas, a capacidade individual de discernir entre o bem e o mal absolutos e, em última análise, a capacidade de escolher, é que estão na intimidade da ação, como manifestação do ser consciente.

As regras morais são contemporâneas do próprio advento da consciência, e julga-se mesmo que pouco tenham evoluído de seis mil anos a esta data 9 a

Há preceitos inscritos nos mais antigos documentos, aos quais nada poderíamos hoje acrescentar, e que nem mesmo têm sido cumpridos. Ptah-Hotep, nas instruções que escreveu para o uso dos príncipes egípcios, ao tempo da quinta dinastia, nos mostra o avançado grau de sabedoria atingido naquela época. Uma passagem, apenas. Escutai.

"Se fôres sábio, cuidarás da tua casa. Acariciarás a tua mulher e alimentá-la-ás. Tu a vestirás e cuidarás dela se adoecer. Encherás seu coração de alegria, durante tôda a sua vida e não serás severo. Serás bom para os teus servos, na possibilidade dos teus meios. A paz e a felicidade se ausentam da casa em que os servos são infelizes..."

Faz cinco mil anos que o sábio professor deu êsse conselho. Quantos anos levará para ser pôsto em prática universal?

Parece possível formular um critério do bem e do mal à luz da

La criminalité suit avec une régularité frappante la courbe des fluctuations éco-

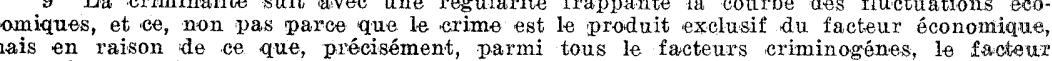
mais en raison de ce que, précisément, parmi tous le facteurs criminogénes, le facteux
économique est de plus mobile, le plus variable et le plus éxposé à des oseillations annuelles, t qu'il exerce partout l'influence la plus apparente et la plus soudaine sur le mourement lacteurs d'ordre organique, d'ordre cosmique et tellurique et d'ordre social, non économique, sont, de nature, sujets a des changements annuels restreints et lents, et partant peu apparents. Leur courbe est presque rectiligne. Done la courbe correspondante de la crimi ariations insensibles et demeure presque identique à elle-même, d'année en an anê. Co ont les oscillations économiques, capricieuses et brusques, qui constituent dans la coube die a criminalité l'éément perturbateur et provoquent les diférences qu'on y remarque d'un 9 a l'autre. (J. Van Kan, Les causes économiques de la criminalité, Paris,
9 Leconte de Notiy - Human Destiny. Ed, Longmans, Nova York, 1947. teoria que concede ao aperfeicoamento do espírito humano o lugardestino de tôda a evolução.

Bem é aquilo que contribui para o curso da evolução ascendente e afasta o homem do animal em direção à liberdade. Mal é o que se opõe à evolução e escapa a ela, impelindo o homem para a servidão ancestral. Em outras palavras, e do ponto de vista estritamente humano, bem é o respeito da personalidade humana; mal é o desprêzo desta personalidade. $O$ dever do homem, portanto, é o desenvolvimento da sua própria dignidade.

A vida nos mostra constantemente um jôgo de fôrças. Em todos os aspectos existe uma interdependência recíproca de ações que não exclui a vontade e a decisão. Esta não é o resultado de um fenômeno anárquico, nem tampouco de um livre arbítrio absoluto, senão de um processo em que atuam conjunta, ainda que desigualmente, o natural e o cultural. A valorização humana, êsse poder estimativo de valores, é o que determina em sua evolução, dentro dos limites empírico-culturais, a compreensão de que a vontade é livre ${ }^{10}$.

Sôbre êste substrato de idéias morais, vivo e palpitante, atravé da consciência livre do homem, agem diversos fatôres. Um dos mais importantes, sem dúvida, é a contingência econômica, e age com sucesso inversamente proporcional ao estado de desenvolvimento dos preceitos morais de que se reveste a personalidade através da sua experiência milenar. Daí, a plausível explicacão da maior ou menor delinqüência de grupos sociais diversos, sujeitos à mesma pressão $E$, ainda, a incidência maior ou menor do crime, num mesmo grupo social, submetido aos diferentes períodos críticos de sua história.

As organizações sociais, segundo a presunção teórica da nossa filosofia social, aparecem-nos estabelecidas na base do critério médio. face as condições médias de vida. A conduta é, portanto, a resultante do jôgo dessas duas variáveis, de tal modo que oscila conforme crescem as fôrças de pressão ambiental e os estímulos externos que se combinam com as reações individuais. E' inadmissível encará-la como produto invariável, um modêlo ajustado à lei, quando se reconhece amplamente a extrema versatilidade de ambos os fatôres de que ela resulta.

Ao estabelecer valores, a lei parte da hipótese ideal de que a capacidade de resistência média do homem enfrenta um ambiente de premências e que, sob estas condições, se deve esperar que êle resolva seus conflitos eventuais, segundo aquêle modêlo ajustado à lei.

Depois de examinar a imensa variedade da conduta criminal,

10 Manuel Lapes Rey y Arrojo - Tendencia, Mundo Circundante y Personalidad ex 
Edwin Sutherland ${ }^{11}$ admite que o processo causal específico do crime reside no desenvolvimento da conduta delituosa sistemática, adotando como certa a fórmula "o crime é a causa do crime".

Von Hentig ${ }^{12}$, conquanto entenda parcialmente correta esta teoria, pensa, pressupondo que a pressão do ambiente que nos rodeia não se eleva acima da média de um grau suportável, que a conduta delituosa é uma adaptação defeituosa ao ambiente social. O homem está em condições de se defender por si mesmo em suas contendas individuais. A sociedade, entretanto, criou uma assoberbante superioridade de fôrças que podem proporcionar o bem-estar ao homem ou se erigir entre êste e o prêmio de seus impulsos mais fortes e mais legítimos. As condições normais são substituídas por colapsos críticos ou situações opressoras.

Inúmeras contradições e dificuldades práticas se opõem àquelas teorias. Mesmo abandonando a conceituação de Von Hentig no que concerne à conduta delituosa genuína referente às condições inatas do agente, voltemo-nos para o ambiente social e diremos, com a opinião dos autores, com a nossa experiência e com os nossos próprios números, que a maior parte dos nossos delinqüentes é produto do meio. São, em regra, indivíduos respeitadores da lei enquanto brilha o sol, enquanto a vida econômica decorre sem tropeços e a sua capacidade de adaptação não é solicitada excessivameços e

Nas organizações altamente industriais, quando se preparam as tormentas sociais e se estabelecem as depressões, quando os preço vacilam, desequilibrando o ritmo econômico que deriva da relação salário-produção, aumenta o número de desocupados. Na nossa economia, ainda extrativa ou puramente agrícola, em que "a indústria é um estado de espírito", o sismo econômico é agravado pela falta de organização do trabalho, pela má educação e pela miséria abrumadora em que vivem, em geral, o jeca dos campos e o crioulo das favelas, componentes básicos do proletariado brasileiro. E êsses fatôres representam, em síntese, a estaca zero da nossa estrutura econômica.

Lembremos o imprevisível desfêcho que teve a elevação do custo de vida quando se procurou corrigi-la com aumentos de salários. Deu-se o retraimento da produção, o aumento da vadiagem e novo lance para cima no custo das comodidades. Num trágico círculo, nova depressão se registrou, já agora com sensíveis repercussões no comportamento coletivo.

Pela barra do Tribunal de Justiça, como num instrumento de

11 E.dwin suthexland - Principles of Criminology - J. B. Lippincott Company, 12 Hans Von Hentig, obr. cit. registro, passaram as vagas da criminalidade, deixando nêle impressas as salsugens indeléveis das suas flutuações.

\section{Material e método}

Os dados que colhemos se referem ao Estado do Rio Grande do Sul e ao período compreendido entre 1940 e 1948.

O número global e anual das denúncias oferecidas em todo o Estado, segundo cifras obtidas na Procuradoria Geral, permite assinalar um notável crescimento da criminalidade, que o gráfico n. ${ }^{\circ} 1$ mostra com surpreendente nitidez.

Há uma indentação à altura dos anos de 1943, 1944 e 1945.

Ainda no mesmo gráfico se registra o movimento do crime no Fôro desta Capital, que segue aproximadamente a mesma linha ascendente e também sofre uma caprichosa indentação nos anos de 1944 e 1945.

Este último detalhe ganha, assim, significação geral e, possìvelmente, traduz efêmera melhoria devido ao tremendo ímpeto industrial impôsto pela guerra, que também se fêz sentir no Brasil.

Para apreciar a ordem econômica no Estado e estabelecer relação com o aumento do crime apontado, fomos nos valer do magnífico trabalho da autoria do estatístico Januário Prates ${ }^{13}$, intitulado Contribuição do Estudo de Problemas Sociais e Econômicos do Rio Grande do Sul.

Esse autor procura avaliar o custo de vida pela despesa média por pessoa, estabelecendo percentagens de aumento. Para realizá-lo, escolheu quatorze produtos, calculou o consumo médio anual por pessoa, determinou o valor total de cada produto e somou todos os valores para chegar à despesa média anual relativa ao período de 1939 a 1946. Finalmente, extraiu a percentagem de aumento entre os anos indicados. Essas determinacões foram feitas para cada uma das regiões geográficas em que está dividido o Estado. Somando os aumentos percentuais e dividindo pelo número de zonas, obteve a média do Estado - $121 \%$.

Não há, é certo, uma correspondência cronológica exata entre a nossa estatística do crime, de 1940 a 1948, e o levantamento econômico de Januário Prates, de 1939 a 1946; mas, a se julgar pela própria tendência ascendente da curva da criminalidade, pode-se esperar retrospectivamente para o ano de 1939 uma cifra ao redor de 2.300 denúncias.

Portanto, houve entre os anos de 1939 a 1946 um aumento de aproximadamente $100 \%$ do crime no Estado, o que representa um

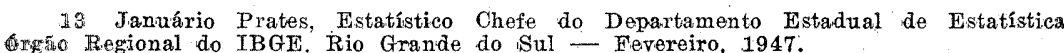


estreito paralelismo com o aumento de $121 \%$ verificado no custo de vida.

Utilizamos, na segunda forma estimativa, um levantamento da população carcerária da Casa de Correção desta Capital, no ano de 1948, relacionando 1.263 condenados pela qualidade da infração, distribuída pelos municípios de origem ${ }^{14}$. Dêsses municípios adotamos a divisão de Januário Prates ${ }^{15}$, conforme a distribuição da propriedade em agrícola e pastoril, formando três grupos ou zonas, preponderantemente pastoril, preponderantemente agrícola e, finalmente, a de economia mista, agrícola, pastoril e com alguma concentração industrial. Se aos municípios de cada um dêsses grupos atribuirmos o coeficiente percentual dos crimes contra o patrimônio, podemos obter a média dos coeficientes para cada grupo, e, então, verificamos que, na zona da pecuária, em que a propriedade pastoril está para a propriedade agrícola como 15 está para 1 , o coeficiente percentual dos crimes contra o patrimônio é de $43 \%$.

Procedemos da mesma forma para as áreas restantes. Os resultados finais estão tabulados no quadro $n .^{\circ} 1$.

Incidentalmente, julgamos oportuno mostrar, em números globais, a distribuição ou tendências do crime no Estado, utilizando, para isso, ainda os 1.262 condenados recolhidos, no ano de 1948, à Casa de Correção desta Capital.

Ressalta do gráfico n. 2 a extraordinária superioridade numérica dos delitos contra o patrimônio. Os crimes contra as pessoas ocupam o segundo lugar, os contra os costumes o terceiro e, assim, sucessivamente.

A distribuição por idade e pelas profissões dos condenados permite, ainda, observar que a percentagem delitual se exacerba naquela fase da vida em que o homem combina a maior fôrça muscular, a maior agilidade mental e os mais violentos desejos de um máximo de atividade, culminando, então, no delito da plena mocidade; e quanto às profissões, se constata que o maior número de criminosos pertence às categorias mais humildes, em que a penúria cria um constante estado de carências ${ }^{16}$

\section{Discussão}

Estão apresentados os elementos que colhemos para êsse trabalho de pesquisas. $E^{\prime}$ chegado o momento de tirar dêles as observações correspondentes e, finalmente, num complemento lógico, a lição útil.

14 Relatório da Seccão Penal e de Expediente, Casa de Correção, 1948.

15 J. Prates, trab. eit.
V. quadro das profissóes dos condenados no apêndice.
V. gráfico n.o 3 .
Nada de paradoxal foi observado, os fatos se ajustam à experiência de outros pesquisadores.

A opinião de Parmelee, que é um dos mais consagrados tratadistas contemporâneos, assim, conclui, depois de um estudo comparativo, em que reproduz gràficamente as tabelas de Von Mayr, Corne e Tarnowski, "(os fatos econômicos) indicam, desde logo, que existe uma relação causal entre o bem-estar econômico e os delitos contra a propriedade"17.

Como ilustração comparativa dos nossos achados damos os gráficos que aquêle autor apresenta (gráficos ns. 4 e 5 ).

Houve sempre resistência em aceitar, oficialmente, a pobreza como causa de delito. Os primeiros estudos sôbre a delinqüência e as condições econômicas se fizeram tardiamente. Tomou-se como descobrimento revolucionário a declaração de $\operatorname{Von} \mathrm{Mayr}^{18}$, feita em 1867:

"Cada níquel de aumento no preço do trigo, durante o período de 1833 a $1861 \ldots$ produziu um roubo a mais em cada cem mil habitantes na Baviera... enquanto que a mesma diminuição de um níquel preveniu um caso de furto na mesma proporção.".

17 Pero mucho más extensamente que os factores económicos estacionales, influyen austrial debida al perfeccionamiento de los métodos de producción. osos factores economicos y de la delincuencia es mareada por las estadísticas de la flucvazión de los precios y las estadísticas de el numero de delitos cometidos o de el número

Los cuadros que acompañam indican la directa correlación entre los precios del irigo y los delitos contra la propriedad en Inglaterra e Gales y en Francia, y entre lo
precios del centeno y los convictos por robo en Rusia. Esos curadros indican que en esa aaciones hay una tendencia general al aumento de los delitos contra la propiedad a medida precios caen. Lia correlación no es siempre exacta, pusto que frecuentemente hay un notable retardo, que no debe ser extranado puesto que se requiere un pequeño tiempo para que esas nes, y hay razon para creer que esa correlación mantiene regularidad en todo el mundo. Wés también posible demostrar la correlación inversa, que existe entre cambios en los jornales $\mathrm{y}$ los delitos contra la propiedad, puesto que segun los jornales aumentan, los Esta correlación no es tan ajustada o tan aparente como la correlación directa aumento. delitos y los precios, porque los jornales cambian más despacio que los precios, y por lo tanto, no pueden tener un efecto inmediato sobre la extensión de la delineuencia.

Ahora bien, cambios en precios y jornales, usualmente causa cambios en el bienestar aconomico de la gan mayoria del pueblo. Un aumento en los precios, especialmente, en el aumento de coste de vida para las clases pobres, puesto que los jornales no aumentan tan deprisa como los precios. De semejante manera, una caída de los jornales puede causar el aumento del precio de vida, aunque esto ocurra raramente, pues los precios acompaña laego, que existe una relación causal èntre el bienestar económico y los delitos contra da propriedad. (Parmelee, pag. 74 a 76, obr. cit.).

E. Fornarini di Verce - La criminalité e le vicende economique l'Italia - Turin, 1894 Bonger, obr. cit
18 G. Von Mart

18. Won Mayr - Statistik der Gerichtlichen Polizei im Königreiche Bayern - 


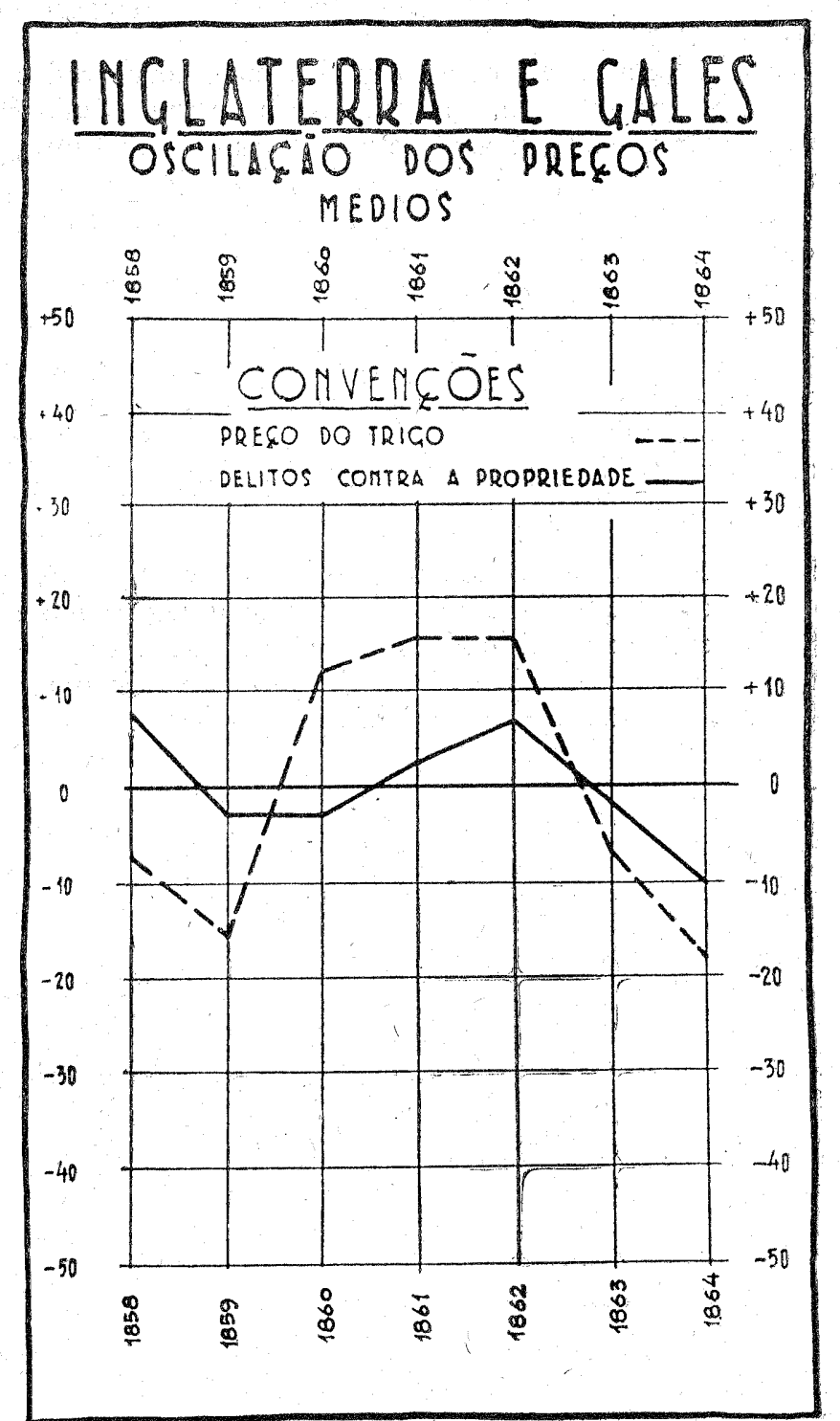

GRÁFICO N: 4 


\section{MOVIMENTO DO CRIME}

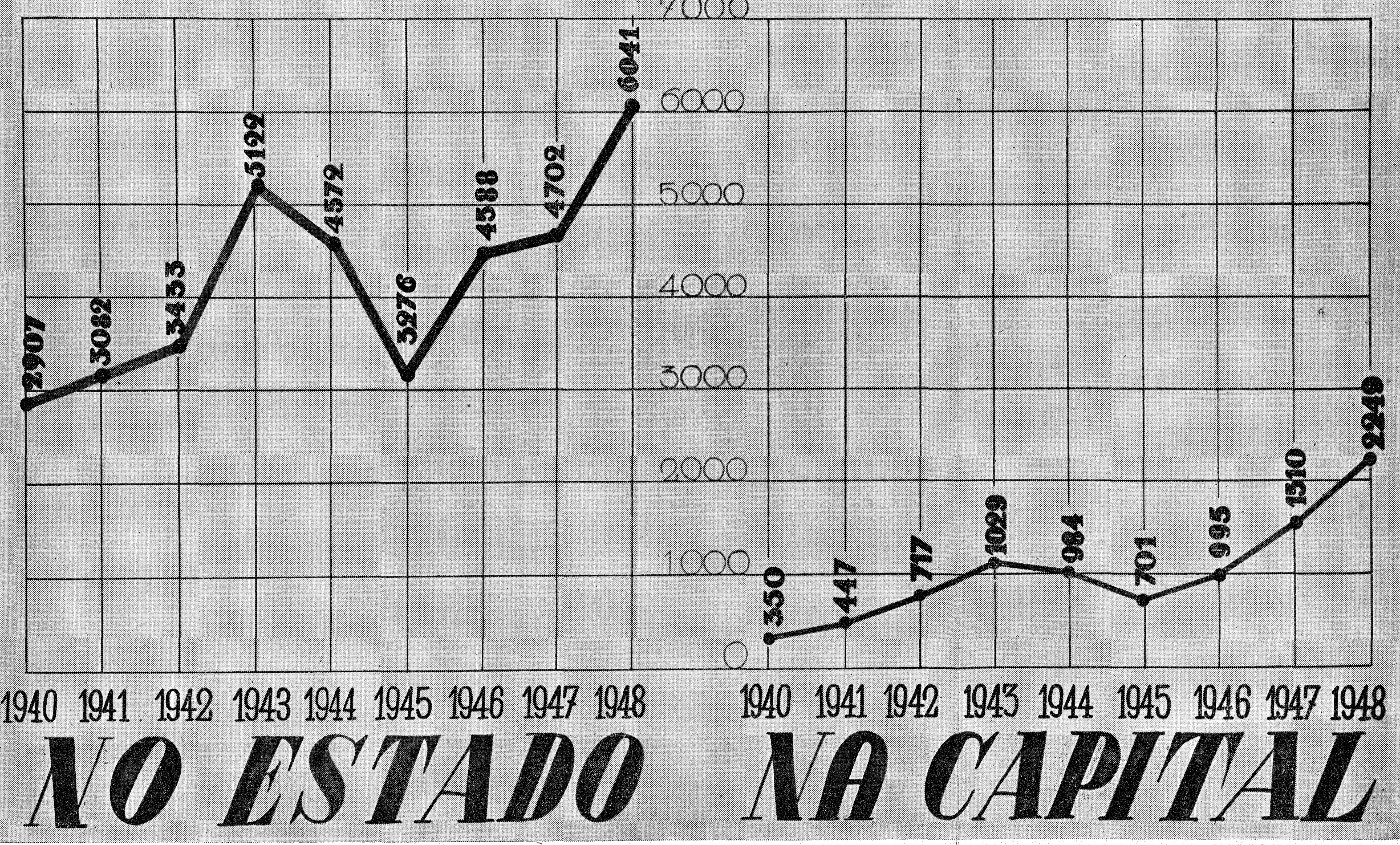




\begin{tabular}{|c|c|c|c|}
\hline ZONAS & 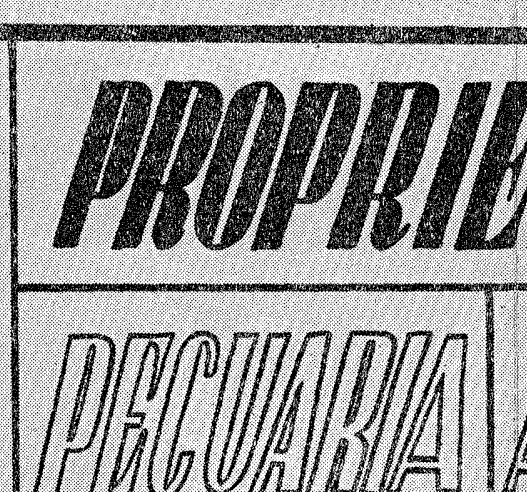 & AAIIE & $\begin{array}{l}\text { CRIMS } \\
\text { COSWRI }\end{array}$ \\
\hline PASTORIL & 15 & 1 & 43.4 \\
\hline MIXTA & 3.3 & 1 & 37. \\
\hline AGRICOLA & 0,74 & 1 & 23 \\
\hline
\end{tabular}




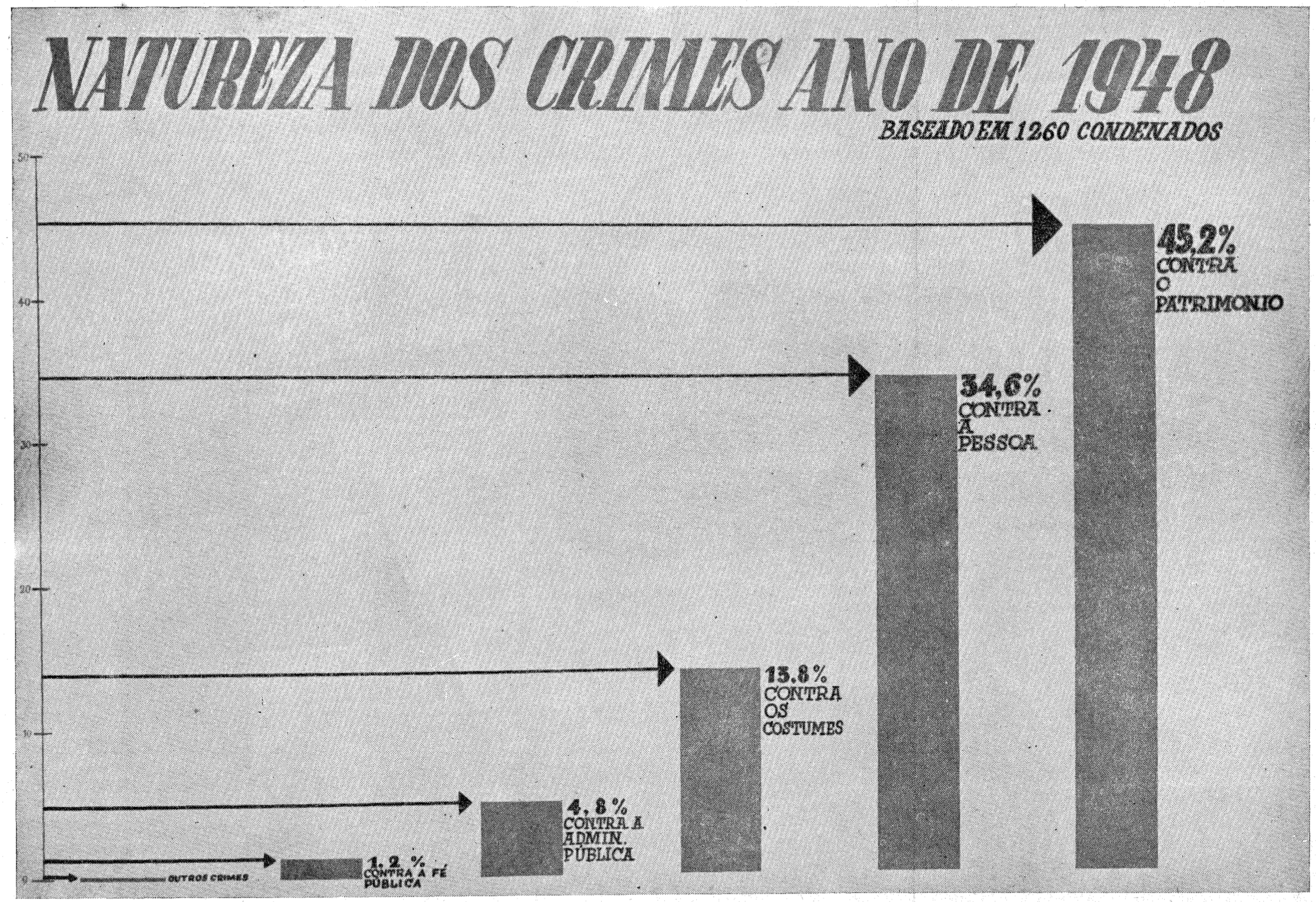




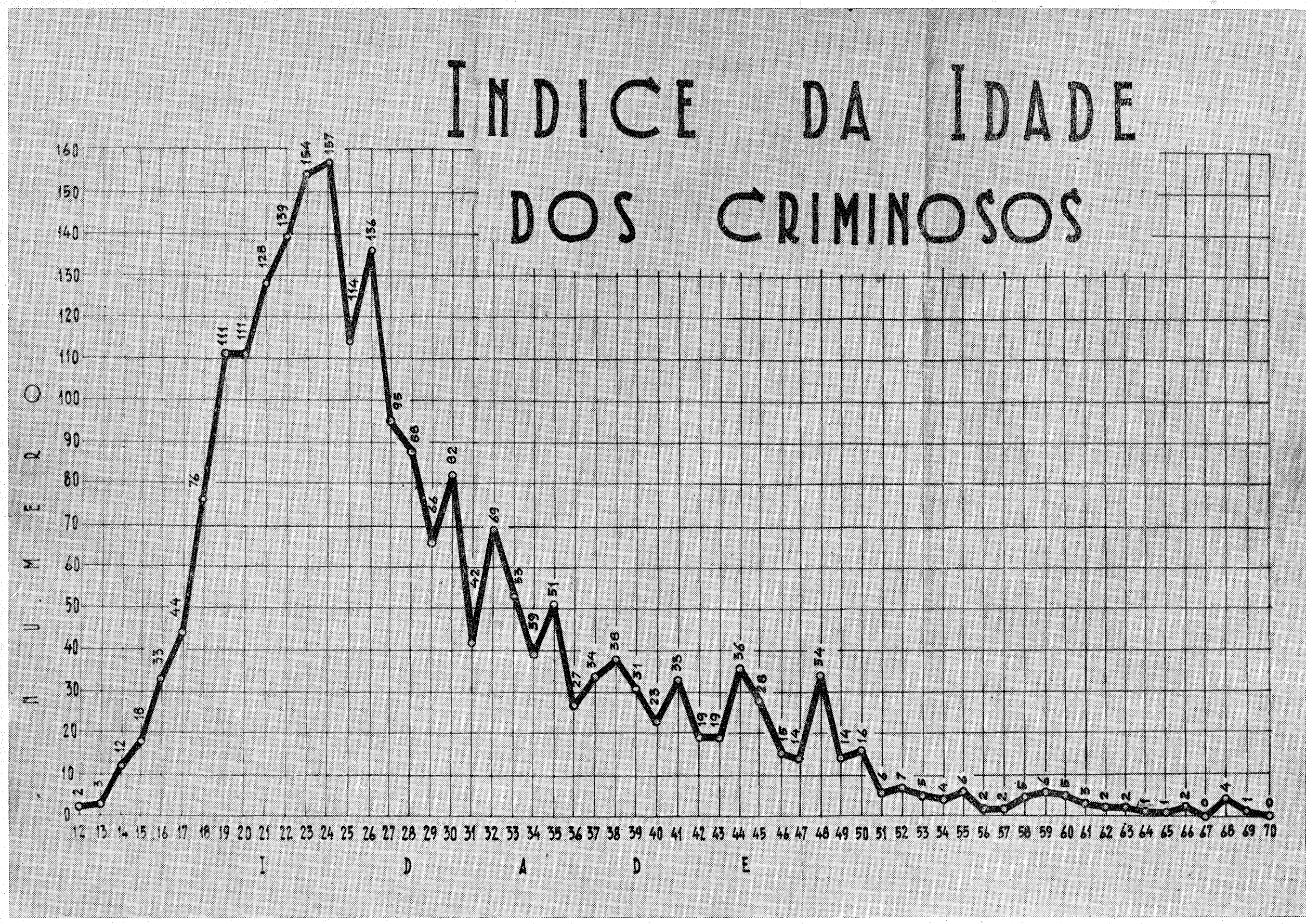


$\mathrm{m}$, que, tanto na Baviera dos meados do século pasRio Grande do Sul de 1940, o preço do pão tem, real significação na conduta coletiva, cujo expoente lo inferior, é representado pelo crime.

udos se fizeram desde aquela época na Europa e em ites. Quase todos confirmaram a tese de Von Mayr. os tipos de prosperidade econômica ou de penúria. - Na Inglaterra e França se tratava do preço do. manha e nos Países Escandinavos, do centeio. Na Bálcans, do milho e no Egito, do algodão. O quadro, 1 claro e convincente nos tempos de Von Mayr e na a, tornou-se gradativamente confuso. Os preços dos. $\mathrm{n}$ substituídos por outros fatôres mais poderosos e ram substituídos pelo índice das matérias-primas, dos sportações' e importações, da produção do ferro e do i sucessivamente. Os índices industriais começaram, lar o aumento e a redução da curva dos delitos.

ão entre os delitos e os índices comerciais é restrin$s$ contra o patrimônio. Os delitos de violência e os. parecem seguir normas diferentes ${ }^{19}$.

a apreciar o nosso gráfico n. ${ }^{\circ} 1$. $O$ declive que se minalidade, nos anos de 1943, 1944 e 1945, coincide om a fase econômica daqueles anos em que a indúsritmo acelerado, em que tôda a produção alcançou s, em que a moeda fácil circulava tonta, em que o L, pràticamente, levado pela mão ao local do trabalho, ários excepcionais. Esse período encerrou-se bruscatambém de súbito, com a cessação das hostilidades, fontes de divisas estrangeiras e a produção nacional aos seus próprios recursos. $\mathrm{O}$ aumento da criminavinha verificando até 1943 , retomou a sua progressão impeto do crescente custo de vida, mas já, agora, em mais graves e apreensivas, porque o recondicionase processar num regime deflacionário, com enormes produção e retraimento total das atividades que delho às massas produtoras. Não se diga que êsse feuas raízes no puro e simples crescimento vegetativo 


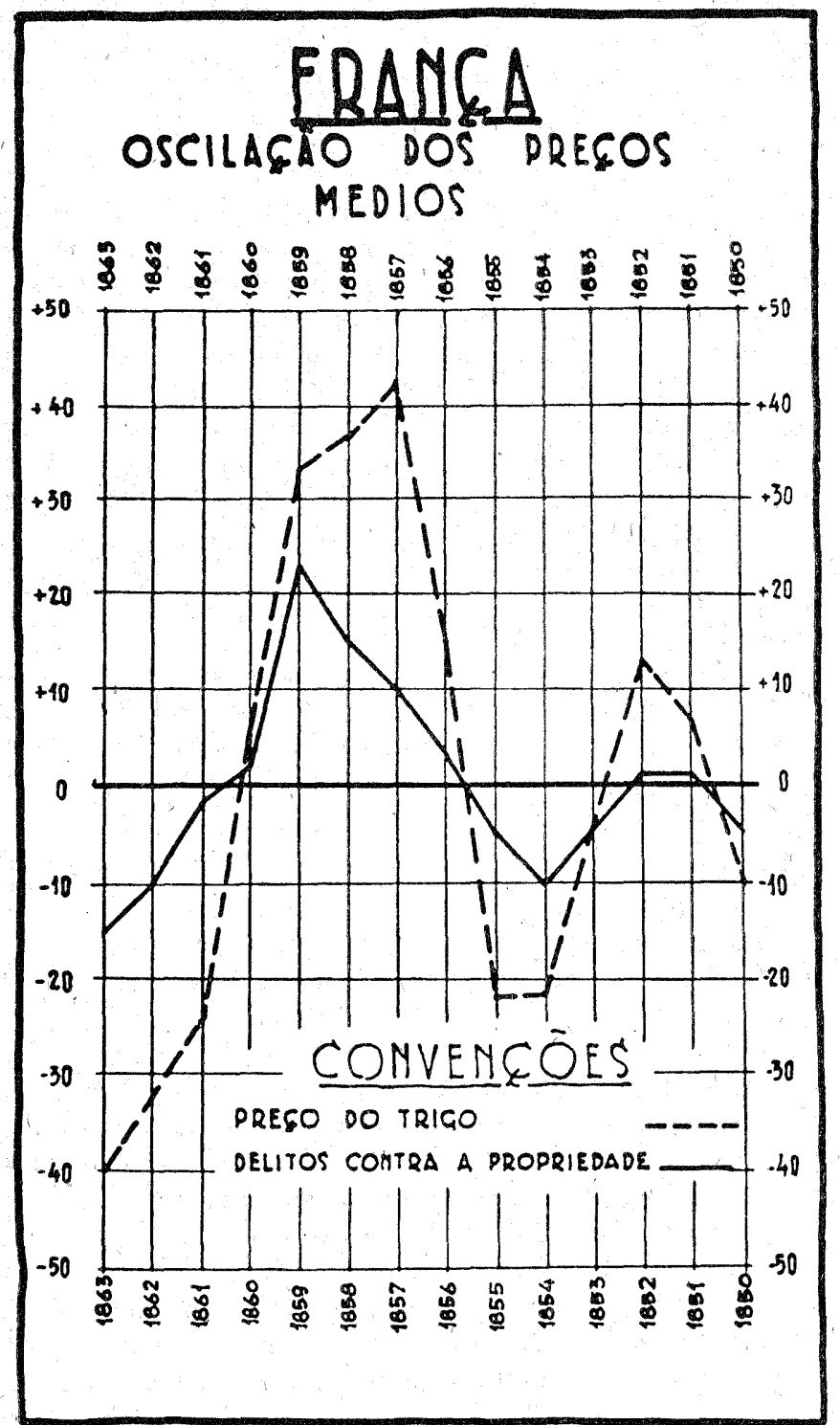

GRÁFICO N. ${ }^{\circ} \quad 5$ da população, pois esta teve, no período de 1940 a 1948 um crescimento, de acôrdo com as estatísticas oficiais, de apenas $17 \%{ }^{20}$.

O panorama social de Pôrtó Alegre ${ }^{21}$, já uma metrópole, contém diversos outros elementos que lhe dão uma posição singular dentro do Estado, embora, em linhas gerais, não constitua uma dissonância absoluta. Com efeito, nas grandes cidades deparamos com problemas oriundos da promiscuidade, da deslocação de massas e do acentuado atrito entre as classes, credos e etnias.

A representação, as tentações, a emulação, os vícios, são elementos desencadeantes de conflitos que assumem feições diversas daqueles que se verificam nos campos e que descrevem uma curva delinqüencial própria dos centros urbanos de grande densidade.

E' o que exatamente se observa no levantamento do gráfico n. ${ }^{\circ}$ 1. Mas, por isso mesmo, por ser uma delinqüência em que a linha causal sofre tantas flutuações fora da esfera econômica, é que nós a julgamos sem propósito nesse trabalho e a deixamos de lado.

Atentemos, agora, ao quadro n. ${ }^{\circ} 2$ que mostra desigualdades comparáveis na distribuição do crime e da propriedade.

E' lícito, desde logo, perguntar, por que devemos considerar como zonas econômicamente inferiores aquelas em que há predominância da grande propriedade.

Evidentemente, a explicação reside no fato de que a riqueza per capita naquela zona é inferior à da zona agrícola, na qual há um equilíbrio razoável entre a pequena e a grande propriedade. Daí o fato de que, naquela, maior é o número dos indivíduos à beira emocional do crime.

Januário Prates ${ }^{22}$, com excelente discernimento, assim se expressa sôbre êsse assunto:

"Sabemos perfeitamente que, nas zonas rurais, existem duas classes distintas: a que tem pouco ou muito e a que nada tem.

A situação de miséria da última classe é total. As famílias, na sua maioria, possuem muitos filhos e nenhum recurso. São verdadeiros marginais do campo, ou melhor, duplos marginais, porque vivem à margem da sociedade e das estradas".

Em contraposição a essas afirmativas, a alentadora cifra refe-

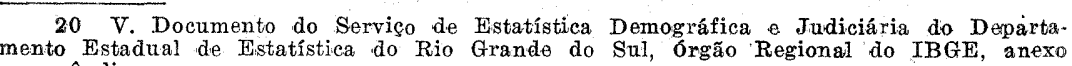
ao apendice.

Hablando del crimen en las regiones civilizadas (Europa en particular), en relación con la densidad de la población, Lombraso dice que: "los robos aumentan con la densidad, Boston, 1911. Apud Parmelee, obr. cit.)
22

16 - R. F. D. 
rente à zona agrícola tem como base a diferença de riqueza que o próprio quadro revela, mas também é certo, e deve ser considerado, que há profundas diferenças culturais entre os dois grupos.

A tradição cultural da zona pecuária remonta em linha direta ao privatismo patriarcal ou semipatriarcal que, segundo Gilberto Freyre, ainda nos domina.

Já as condições prevalentes na colônia derivam de raízes que são um transplante direto da Europa democratizada do último século.

Aquêle privatismo patriarcal cria, através de sua elite, fôrças psicofisiológicas capazes de exercer contrôle sôbre as classes inferiores que, por sua própria subordinação econômica incondicional, esperam de cima o princípio e a receita do seu processo de comportamento social.

$\mathrm{O}$ colono é poupado às imposições feudais. Traz dentro de si mesmo os gérmens de uma concepção própria de vida, com disciplina e norma comuns. Apenas na aparência tem o homem da colônia tomado do antigo senhor da terra o gesto, a voz e, mesmo, algo do ritual. No fundo, há diferença fundamental de temperamento e, ainda que não houvesse, a divisa próxima da pequena propriedade estaria ali a limitar a proporções escassas o mandonismo que quisesse copiar.

Tanto quanto os fatôres econômicos, é iniludível a influência que podem exercer sôbre o comportamento coletivo êsses motivos culturais.

$\mathrm{Na}$ zona mista, afinal, uma simples mistura dos componentes essenciais da lavoura e da sesmaria, temos, também, a média numérica no percentual de crimes contra a propriedade. Esta região desempenha, portanto, o papel de assessor de valores, qual se fôra uma contraprova das nossas observações.

Afigura-se-nos de pouca significação, porque extremamente diluída, a presença de núcleos industriais pelo interior do Estado.

Os números absolutos da massa operária são, na realidade, insignificantes, como se vê, ainda no trabalho de Januário Prates, em que mesmo Pôrto Alegre aparece com 28.330 operários, isto em 1946, quando a população da Capital se estimava em 386.400 habitantes.

O que será em Cachoeira, Pelotas, Santa Maria, Livramento, Rosário, Bagé?

Em números relativos, eis as percentagens ${ }^{23}$ :

Pôrto Alegre ........... 1,08\%

Santa Maria ............. $1,4 \%$

Livramento $. . \ldots \ldots \ldots \ldots .3,6 \%$

23 J. Prates, trab. cit.

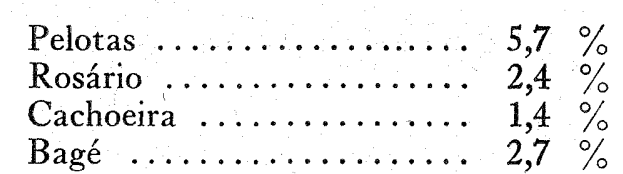

Em trabalho desta natureza, é sempre necessário fazer uma aferição tão correta quanto possível.

O método estatístico é essencialmente o método dos grandes números ou das amostras représentativas dos grandes números.

Exatamente, em nosso trabalho, pretendemos que os dados colhidos na Casa de Correção constituam uma amostra representativa do crime no Estado. Será honesto dizer, entretanto, que êstes números representam apenas uma parte da verdade, nem de longe tôda a verdade, mas tôda a verdade acessível. Não há outra.

Como contar os peixes que escapam às malhas da rêde e os que nem sequer vêm à rêde?

Sabemos, e é de consenso universal, que a justiça, curiosamente, se mostra mais rígida com relação aos delitos contra o patrimônio, mais magnânima com os delitos sexuais. Em tudo há o elemento imponderável da simpatia de classe, do sexo e da cultura.

Mesmo assim, o proletário do crime que reside no cárcere representa a súmula significativa das condições sociais vigorantes.

Se as condenações por furto crescem, pode-se razoàvelmente admitir também, que contra essa modalidade de crime se ergue mais severa do que antes a justiça punitiva. A condenação, portanto, não é mais do que a soma do delito provado e do rigor judiciário exacerbado pela própria conjuntura econômica.

Admitimos, assim, que o veio estatístico minerado tem as limitações que apontamos, mas tem, sobretudo, o valor da síntese, e o valor do fato incontrovertido, verídico.

\section{Conclusões}

1. Verificou-se no Rio Grande do Sul um sensível aumento da criminalidade no período compreendido entre 1940 e 1948 , aumento que acompanhou o crescente custo de vida durante o mesmo período. Existe, ademais, indiscutível coincidência entre ambos os ritmos de crescimento, o que permite relacioná-los como causa e efeito. Esta presunção é consideràvelmente fortalecida pela conclusão imediata.

2. Nas áreas de menor equilíbrio de riqueza, os crimes contra o patrimônio são de muito maior freqüência, o que é, provàvelmente, devido à distribuição desproporcional daquela:

A lei científica e universal que estabelece a íntima relação entre as perturbações econômicas e a conduta coletiva, foi, assim, comprovada à luz de uma experiência que se prolonga ainda. 


\section{$A \mathbf{P} \hat{\mathbf{E}} \mathbf{N} D I C \mathbf{E}$}

MUNICIPIOS PASTORI

\begin{tabular}{|c|c|c|c|}
\hline \multirow{2}{*}{ MUNIChípios } & \multicolumn{2}{|c|}{ Riqueza Média } & \multirow{2}{*}{$\begin{array}{c}\text { Crimes } \\
\text { contra. } \\
\text { patrimônio } \\
\%\end{array}$} \\
\hline & Pecuária & Agrícola & \\
\hline Alegrete & 6.150 & 200 & 62,5 \\
\hline Cacequi ..... & 6.419 & $698^{\circ}$ & 33,3 \\
\hline Dom Pedrito ........ & 6.557 & 32 & 47,5 \\
\hline Quarai .............. & 5.643 & 110 & 50,0 \\
\hline São Gabriel & 3.687 & 210 & 63,5 \\
\hline Uruguaiana ... & 7.636 & 275 & 23,4 \\
\hline Arroio Grande ......... & 4.486 & 1.080 & 33,3 \\
\hline 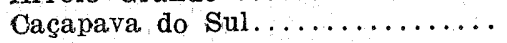 & 4.355 & 116 & 0 \\
\hline Cangussu $\ldots \ldots \ldots \ldots \ldots \ldots \ldots$ & 1.404 & 328 & 30,0 \\
\hline 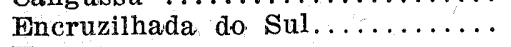 & 2.380 & 428 & 45,0 \\
\hline 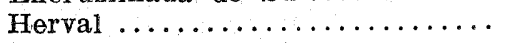 & 9.343 & 145 & 63,6 \\
\hline Jaguarão ….......... & 3.600 & 328 & 76,4 \\
\hline Lavras do Sul..... & 7.655 & 167 & 100,0 \\
\hline Pinheiro Machado & 7.933 & 130 & 28,5 \\
\hline Piratini ............. & 3.861 & 307 & 25,0 \\
\hline Itaqui ... & 7.128 & 502 & 33,3 \\
\hline Santiago .. & 3.700 & 85 & 20,0 \\
\hline São Borja .............. & 5.972 & 378 & 40,5 \\
\hline São Farncisco de Assis........... & 5.324 & 514 & 33,3 \\
\hline Aparados da Serra................... & 5.604 & 115 & 33,3 \\
\hline Santa Vitória do Palmar........... & 8.740 & 216 & 69,2 \\
\hline General Vargas $\ldots \ldots \ldots \ldots \ldots \ldots$ & 4.148 & 477 & 21,3 \\
\hline 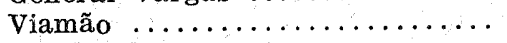 & 1.721 & 663 & 60,0 \\
\hline Rio Pardo $\ldots . . .$. & 1.077 & 746 & 40.0 \\
\hline 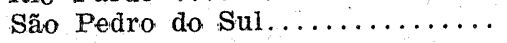 & 1.379 & 265 & 10,0 \\
\hline
\end{tabular}

MUNICIPIOS PASTORIS, AGRfCOLAS I INDUSTRIAIS

\begin{tabular}{|c|c|c|c|}
\hline Pôrto Alegre $\ldots \ldots \ldots \ldots \ldots \ldots$ & & 16 & 57,0 \\
\hline Bagé ......... & 3.702 & 100 & 48,1 \\
\hline Livramento ... & 3.678 & 351 & 20,0 \\
\hline Rosário do Sul. & 5.672 & 436 & 31,7 \\
\hline Tupanciretã ... & 4.439 & 182 & 50,0 \\
\hline Pelotas ......... & 204 & 402 & 56,9 \\
\hline Rio Grande ..... & 426 & 715 & 76,5 \\
\hline Caxias do sul.................. & 228 & 524 & 50,0 \\
\hline 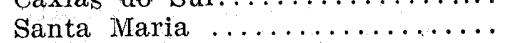 & 750 & 208 & 33,3 \\
\hline 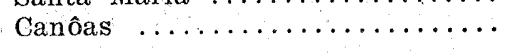 & 283 & 314 & 33,3 \\
\hline
\end{tabular}

\begin{tabular}{|c|c|c|c|}
\hline \multirow{2}{*}{ MUNICIPIOS } & \multicolumn{2}{|c|}{ Riqueza Média } & \multirow{2}{*}{$\begin{array}{c}\text { Crimes } \\
\text { contra } \\
\text { patrimônio } \\
\%\end{array}$} \\
\hline & Pecuária & Agricola & \\
\hline 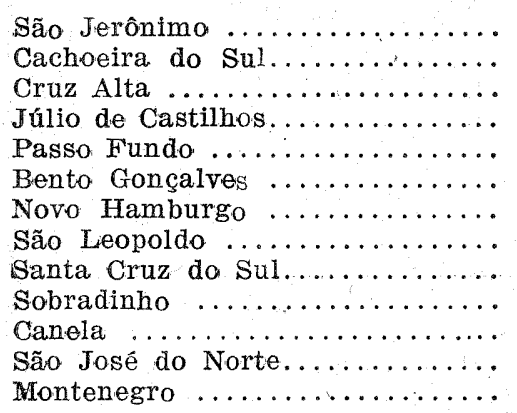 & $\begin{array}{r}756 \\
1.773 \\
2.836 \\
4.403 \\
610 \\
345 \\
163 \\
355 \\
720 \\
660 \\
272 \\
1.846 \\
563\end{array}$ & $\begin{array}{r}219 \\
572 \\
375 \\
417 \\
261 \\
1.062 \\
53 \\
198 \\
871 \\
720 \\
224 \\
1.758 \\
403\end{array}$ & $\begin{array}{r}23,0 \\
37,5 \\
16,6 \\
50,0 \\
43,9 \\
7,1 \\
33,3 \\
23,2 \\
51,8 \\
33,3 \\
33,3 \\
0 \\
47,8\end{array}$ \\
\hline
\end{tabular}

MUNICIPIOS AGRÍCOLAS

\begin{tabular}{|c|c|c|c|}
\hline Antônio Prado ........ & 788 & 750 & \\
\hline Arroio do Meio.......... & 8120 & 1.029 & 33,3 \\
\hline Caí $\ldots \ldots \ldots \ldots \ldots \ldots \ldots$ & 303 & 655 & 33,3 \\
\hline Candelária $\ldots . . \ldots \ldots$. & 725 & 1.246 & 37,5 \\
\hline Encantado & 774 & 319 & 90,0 \\
\hline Estrêla .... & 1.301 & 1.302 & 69,2 \\
\hline Farroupilha ........ & 395 & 1.032 & 0 \\
\hline Flôres da Cunha $\ldots \ldots \ldots \ldots \ldots \ldots$ & 445 & 1.060 & 0 \\
\hline Garibaldi $\ldots \ldots \ldots \ldots \ldots$ & 810 & 627 & 33,3 \\
\hline Guaporé ..... & 673 & 488 & 0 \\
\hline Lajeado ... & 897 & 992 & 33,3 \\
\hline Nova Prata ........... & 754 & 1.144 & 0 \\
\hline Santo Antônio $\ldots \ldots \ldots \ldots \ldots . . . . .$. & 326 & 930 & 13,0 \\
\hline Taquara $\ldots \ldots \ldots \ldots \ldots \ldots$ & 699 & 815 & 48,7 \\
\hline Taquari & 507 & 2.186 & 0 \\
\hline Venâncio Aires $\ldots \ldots \ldots \ldots \ldots \ldots$ & 484 & 567 & 0 \\
\hline Veranópolis $\ldots \ldots \ldots \ldots \ldots \ldots \ldots$ & 589 & 729 & 0 \\
\hline Santa Rosa $\ldots \ldots \ldots \ldots \ldots \ldots \ldots$ & 530 & 1.289 & 29,4 \\
\hline São Luiz Gonzaga....... & 1.651 & 1.046 & 34,0 \\
\hline
\end{tabular}

Januário Prates - Contribuição ao Estudo dos Problemas Sociais e Er.conômicos do Rio Grande do Sul - Dados que serviram de base ao quadro $n$. 1, sendo que a percentagem dos crimes contra o patrimonio foi por nos a acrescentada, de acordo com a siluação decurso do mesmo ano, em relação, quantitativamente, às localidades do interior do Estado, de onde procederam, $\theta$ aos respectivos delito 
CUSTO DA VDA

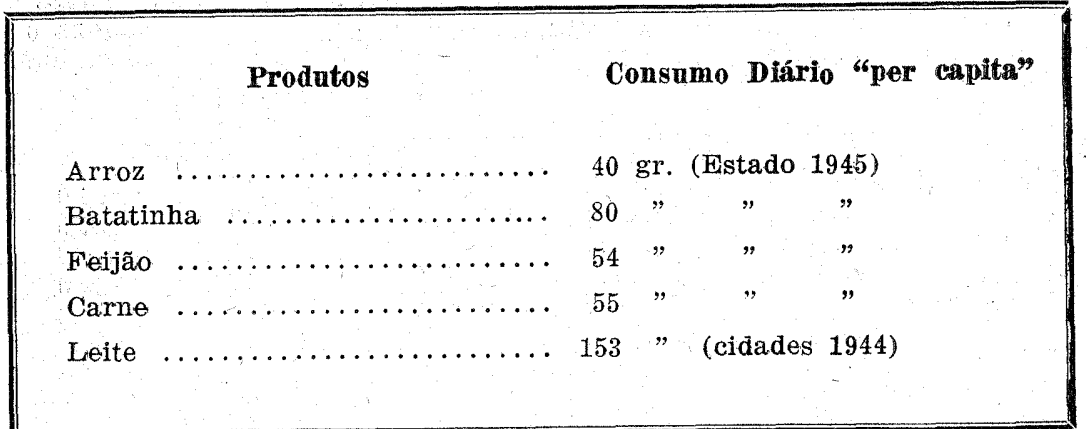

despesa Médi por pessoa e percentagens DE AUMENTO dO CUSTO DA VIDA

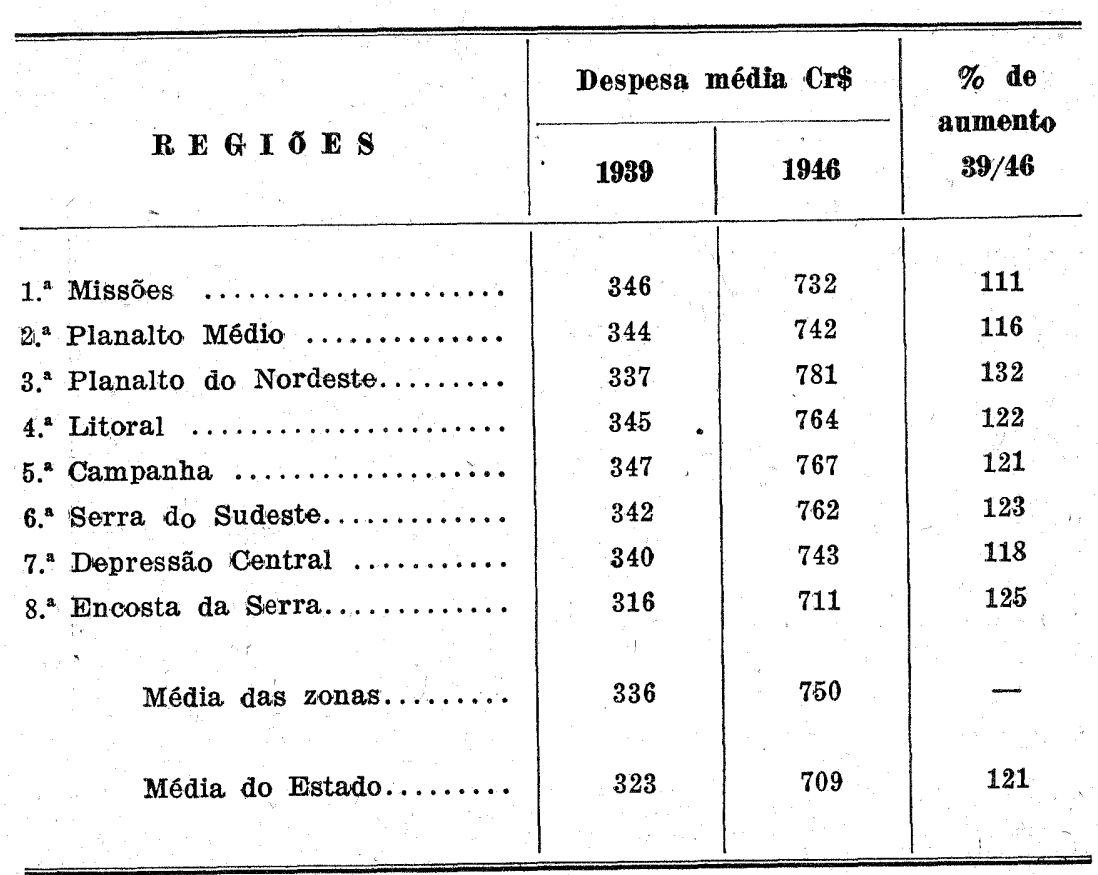

J. Prates, trab. cit.

\section{A D O S G E R A I S}

Custo de Vida - Riqueza Pecuária e Agrícola - Crimes contra o Patrimônio

Anos $39 / 46$

\begin{tabular}{|c|c|c|c|c|}
\hline \multirow{2}{*}{ Municípios e Regiões } & \multirow{2}{*}{$\begin{array}{c}\text { A umento do } \\
\text { custo da } \\
\text { vida \% }\end{array}$} & \multicolumn{2}{|c|}{ Riqueza Média } & \multirow{2}{*}{$\begin{array}{c}\text { Crimes } \\
\text { contra o } \\
\text { patrimônio } \\
\%\end{array}$} \\
\hline & & Pecnária & Agrícola & \\
\hline \multicolumn{5}{|l|}{ Miksões } \\
\hline 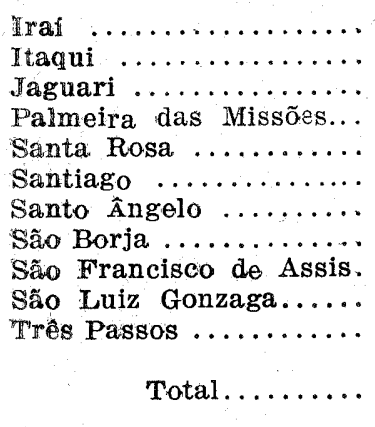 & $\begin{array}{r}96 \\
121 \\
106 \\
106 \\
133 \\
97 \\
124 \\
125 \\
111 \\
93 \\
- \\
110\end{array}$ & $\begin{array}{r}411 \\
7.128 \\
740 \\
928 \\
530 \\
3.700 \\
1.320 \\
5.972 \\
5.324 \\
1.651 \\
- \\
1.753\end{array}$ & $\begin{array}{r}412 \\
502 \\
381 \\
140 \\
1.289 \\
85 \\
156 \\
378 \\
514 \\
1.046 \\
448 \\
\\
588\end{array}$ & $\begin{array}{l}50,0 \\
33,3 \\
29,6 \\
24,6 \\
29,4 \\
20,0 \\
35,5 \\
40,5 \\
33,3 \\
34,0 \\
0\end{array}$ \\
\hline \multicolumn{5}{|l|}{ Planalto Médio } \\
\hline 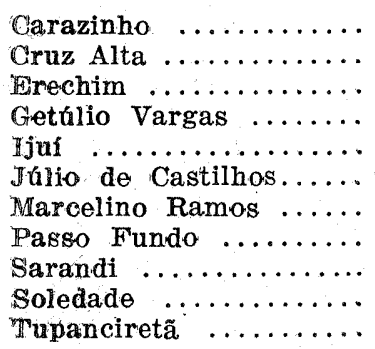 & $\begin{array}{r}105 \\
97 \\
120 \\
107 \\
117 \\
135 \\
-104 \\
130 \\
115 \\
126\end{array}$ & $\begin{array}{r}785 \\
2.836 \\
851 \\
1.748 \\
961 \\
4.403 \\
833 \\
610 \\
1.634 \\
1.376 \\
4.439\end{array}$ & $\begin{array}{l}535 \\
375 \\
838 \\
686 \\
709 \\
417 \\
524 \\
261 \\
461 \\
307 \\
182\end{array}$ & $\begin{array}{l}25,0 \\
16,6 \\
25,5 \\
28,6 \\
42,2 \\
50,0 \\
25,0 \\
43,9 \\
18,5 \\
33,3 \\
50,0\end{array}$ \\
\hline $\begin{array}{l}\text { Total.......... } \\
\text { Planalto do Nordeste }\end{array}$ & 116 & 1.413 & 497 & \\
\hline $\begin{array}{l}\text { Aparados da Serra....... } \\
\text { Lagóa Vermelha } . . . . . \\
\text { são Francisco de Paula } \\
\text { Vacaria ............... }\end{array}$ & $\begin{array}{l}134 \\
112 \\
136 \\
147\end{array}$ & $\begin{array}{l}5.604 \\
2.006 \\
3.144 \\
2.042\end{array}$ & $\begin{array}{r}115 \\
718 \\
61 \\
199\end{array}$ & $\begin{array}{l}33,3 \\
19,3 \\
20,8 \\
36,9\end{array}$ \\
\hline Total.......... & 132 & 2.686 & 377 & \\
\hline
\end{tabular}




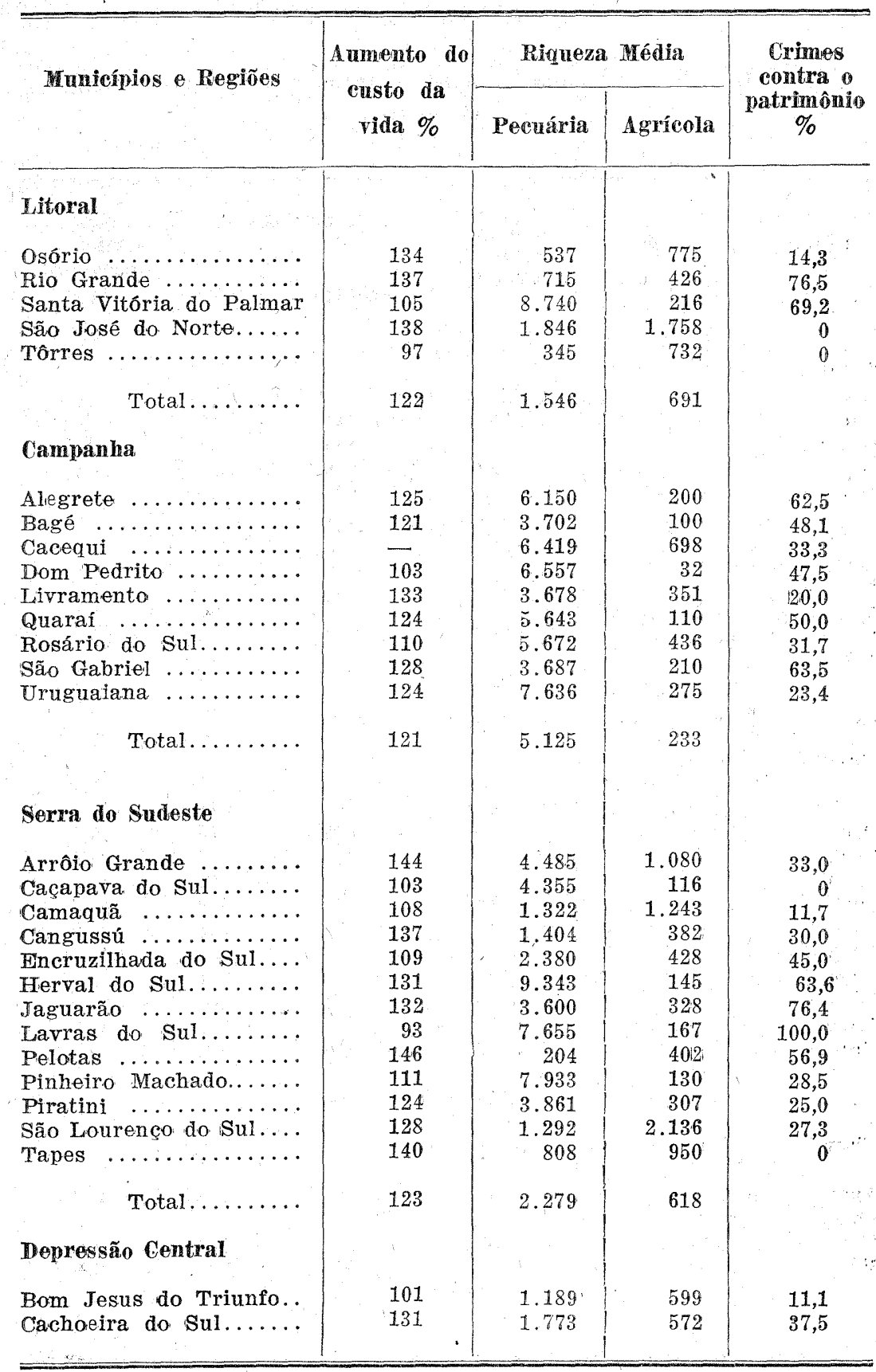

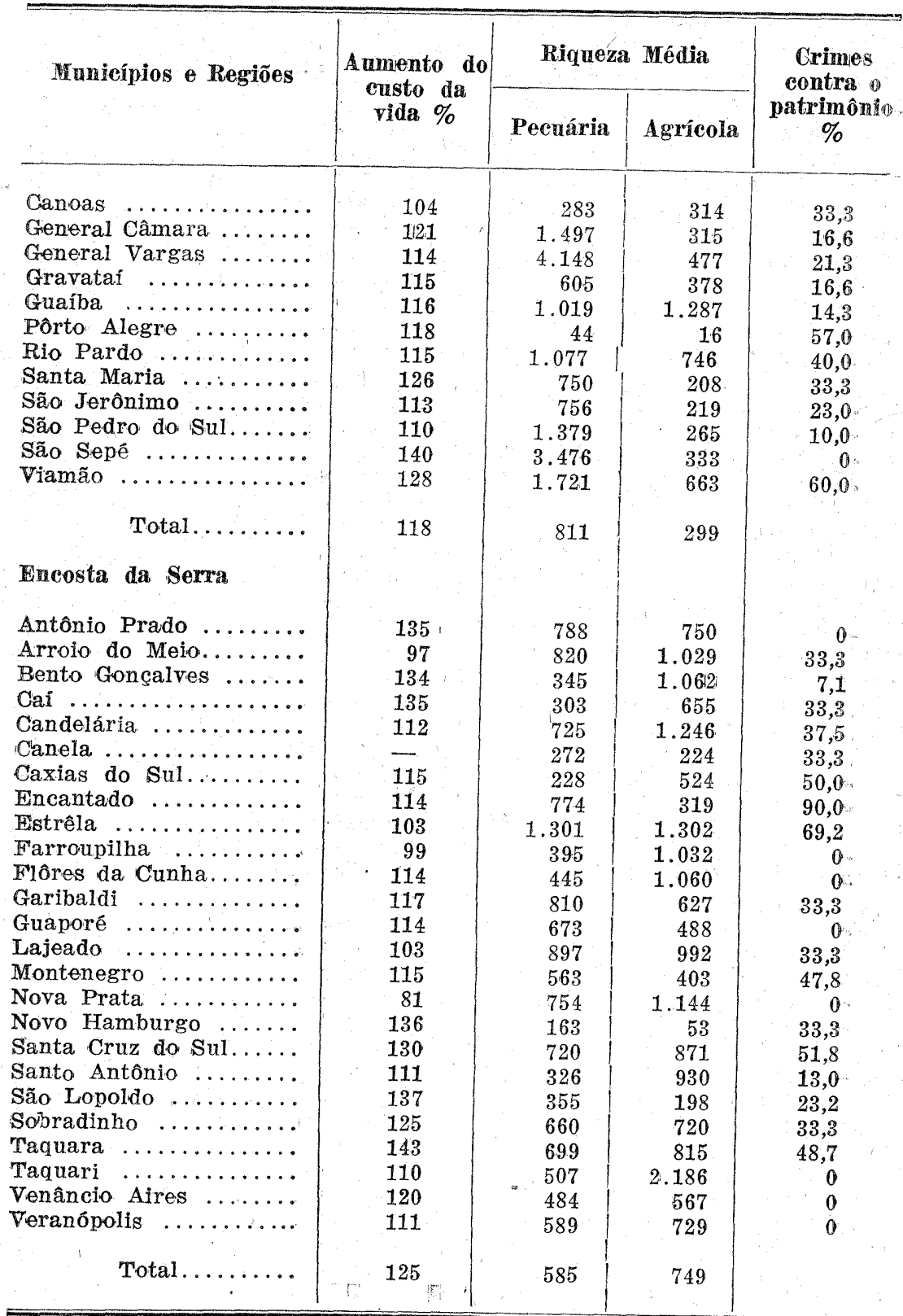




\section{QUADRO DAS PROFISSÓES DOS CONDENADOS}

$$
\text { 2.272 Condenados }
$$

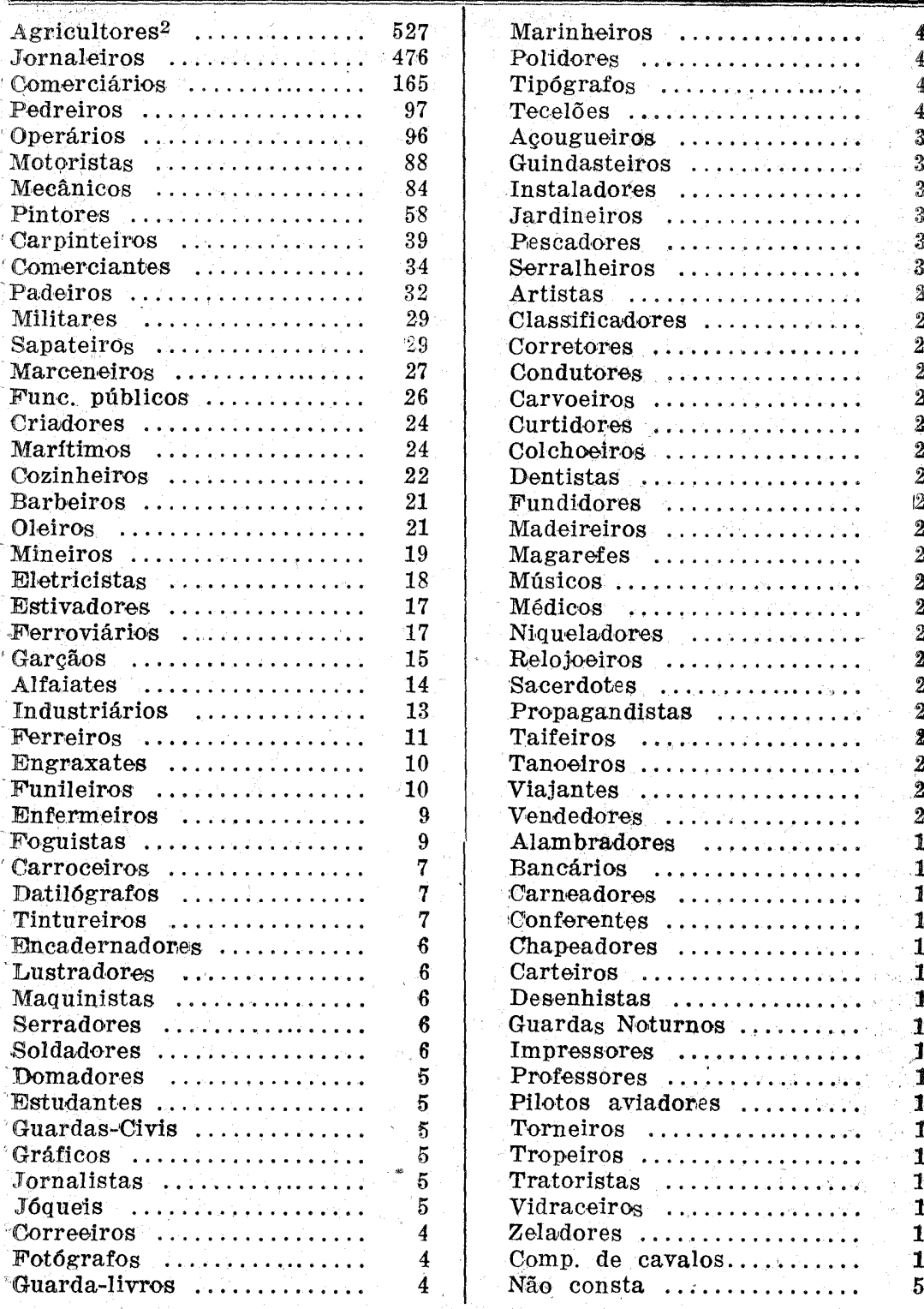

1 Relatório da Casa de Correção - 1948

Não consta
DEPARTAMENTO ESTADUAL DE ESTATísticA

(Órgão Regional do I. B. G. E.)

Rio Grande do Sul - Brasil

Servico de estatistica Demográfica e Judiciária

ESTTMATIVA DA POPULACão

\begin{tabular}{|c|c|c|c|}
\hline & $\therefore \quad n$ & Pôrto Alegre & Estado \\
\hline $31 / 112 / 40$ & $\cdots$ & 276.600 & 3.395 .310 \\
\hline $31 / 12 / 41$ & n.......... & 282.550 & 3.444 .055 \\
\hline $31 / 12 / 42$ & $\ldots \ldots \ldots \ldots$ & 286.560 & 3.511 .830 \\
\hline $31 / 12 / 43$ & $\cdots \cdots$ & 294.480 & 3.578 .620 \\
\hline $31 / 12 / 44$ & $\cdots$ & 300.450 & 3.651 .150 \\
\hline $31 / 12 / 45$ & $\ldots \ldots$ & 306.400 & 3.723 .690 \\
\hline $31 / 12 / 46$ & $\ldots \ldots \ldots \ldots \ldots \ldots \ldots$ & 313.900 & 3.809 .730 \\
\hline $31 / 12 / 47$ & $\ldots \ldots \ldots \ldots \ldots$ & 321.500 & 3.902 .540 \\
\hline $31 / 12 / 48$ & . & 329.100 & 3.991 .490 \\
\hline
\end{tabular}

visto

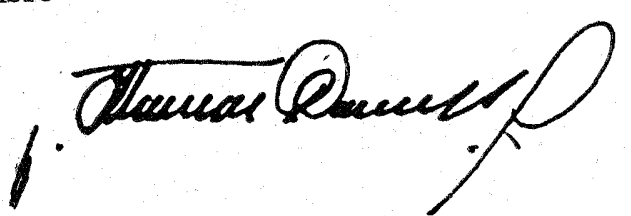

DIRETOR GERAL

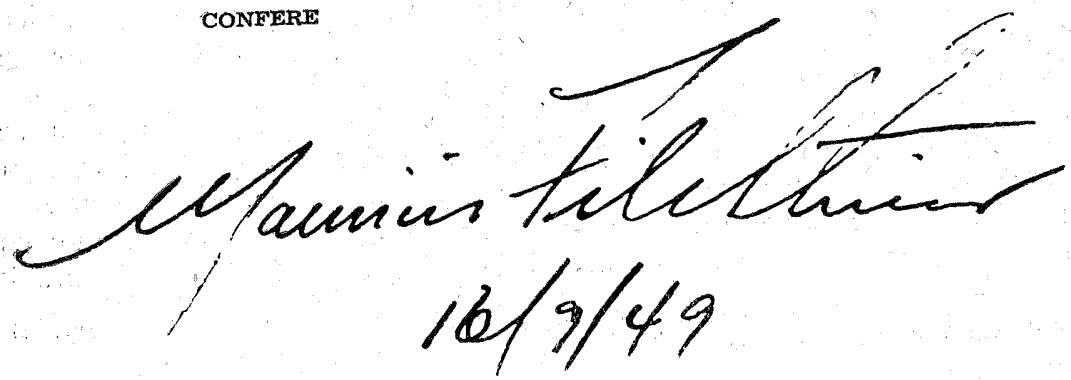

raral ou Na grande maioria năo são proprietários e sim empregados ou peăes nas zona 